\title{
Replacement of $\alpha$-galactosidase $A$ in Fabry disease: effect on fibroblast cultures compared with biopsied tissues of treated patients
}

\author{
Jana Keslová-Veselíková • Helena Hůlková • \\ Robert Dobrovolný • Befekadu Asfaw . \\ Helena Poupětová • Linda Berná • Jakub Sikora • \\ Lubor Goláň • Jana Ledvinová • Milan Elleder
}

Received: 18 June 2007 /Revised: 21 December 2007 / Accepted: 20 January 2008 / Published online: 20 March 2008

(C) Springer-Verlag 2008

\begin{abstract}
The function and intracellular delivery of enzyme therapeutics for Fabry disease were studied in cultured fibroblasts and in the biopsied tissues of two male patients to show diversity of affected cells in response to treatment.
\end{abstract}

J. Keslová-Veselíková, H.Hůlková and R. Dobrovolný contributed equally to this work.

J. Keslová-Veselíková $\cdot$ H. Hůlková $\cdot$ R. Dobrovolný $\cdot$ B. Asfaw $\cdot$

H. Poupětová $\cdot$ L. Berná $\cdot J$. Sikora $\cdot J$. Ledvinová $(\bowtie) \cdot$

M. Elleder $(\bowtie)$

Institute of Inherited Metabolic Disorders,

Bldg. D, Division B; Ke Karlovu 2, 128 08,

Prague 2, Czech Republic

e-mail: jledvin@cesnet.cz

e-mail: melleder@cesnet.cz

J. Keslová-Veselíková

e-mail: jana.keslova@seznam.cz

H. Hůlková

e-mail: helena.hulkova@1f1.cuni.cz

R. Dobrovolný

e-mail: robert.dobrovolny@1f1.cuni.cz

B. Asfaw

e-mail: basfaw@cesnet.cz

H. Poupětová

e-mail: helena.poupetova@1f1.cuni.cz

L. Berná

e-mail: lindaberna@yahoo.com

J. Sikora

e-mail: jakub.sikora@1f1.cuni.cz

L. Golán̆

Clinical Department of Cardiology and Angiology,

First Faculty of Medicine and University Hospital,

U nemocnice 2, 128 08, Prague 2, Czech Republic

e-mail: lubor.golan@seznam.cz
In the mutant fibroblasts cultures, the final cellular level of endocytosed recombinant $\alpha$-galactosidases A (agalsidases, Fabrazyme $^{\mathrm{TM}}$, and Replagal ${ }^{\mathrm{TM}}$ ) exceeded, by several fold, the amount in control fibroblasts and led to efficient direct intra-lysosomal hydrolysis of $\left({ }^{3} \mathrm{H}\right) \mathrm{Gb} 3 \mathrm{Cer}$. In contrast, in the samples from the heart and some other tissues biopsied after several months of enzyme replacement therapy (ERT) with Fabrazyme ${ }^{\mathrm{TM}}$, only the endothelial cells were free of storage. Persistent Gb3Cer storage was found in cardiocytes (accompanied by increase of lipopigment), smooth muscle cells, fibroblasts, sweat glands, and skeletal muscle. Immunohistochemistry of cardiocytes demonstrated, for the first time, the presence of a considerable amount of the active enzyme in intimate contact with the storage compartment. Factors responsible for the limited ERT effectiveness are discussed, namely post-mitotic status of storage cells preventing their replacement by enzyme supplied precursors, modification of the lysosomal system by longstanding storage, and possible relative lack of Sap B. These observations support the strategy of early treatment for prevention of lysosomal storage.

Keywords $\alpha$-Galactosidase A deficiency.

Enzyme replacement therapy - Persistent storage ·

Enzyme targeting $\cdot$ Clearance of storage lysosomes

\section{Introduction}

Fabry disease (MIM 301500) is an X-linked deficiency of $\alpha$-galactosidase A ( $\alpha$-GALA, EC 3.2.1.22) leading to widespread lysosomal accumulation of glycosphingolipids with terminal $\alpha$-galactosyl moieties (mainly globotriaosyl- 
ceramide, $\mathrm{Gb}_{3} \mathrm{Cer}$ ). The ensuing phenotype at the clinical level is well known, including its organ-limited milder variants in hemizygous males and in females who are mosaic hemizygotes $[9,10]$. The dominating therapeutic approach, enzyme replacement therapy (ERT), is based on substitution of the missing enzyme with recombinant $\alpha$ galactosidases, Fabrazyme ${ }^{\mathrm{TM}}$ (agalsidase beta, Genzyme) or Replagal $^{\mathrm{TM}}$ (agalsidase alfa, SHGT) $[6,13]$. Despite differences in the glycosylation pattern due to different expression systems $[14,41]$, both enzymes appear to be functionally indistinguishable from each other [3, 23]. The essential requirement for successful ERT of Fabry disease is the delivery of a sufficient dose of the enzyme into the storage lysosomal compartment. The effect on storage has been evaluated either by monitoring the level of storage or the induction of enzyme activity [12, 21, 3 , 23, 33]. However, there is not any report demonstrating complete clearance of the storage lysosomal system generally. The effect is mostly restricted to endothelia, but the partial clearance effect has been seen by some authors also in another cells, e.g., in the kidney [15].

The goal of this study was to compare effectiveness of ERT in two cell systems: by cultured mutant fibroblasts on one side, representing dynamic cell population minimally modified by low degree spontaneous storage, and transiently exposed to trace amount of tritiated substrate to follow its catabolic pathway. This in vitro experimental system was compared to the situation in vivo, represented by a series of cell types of various regeneration capacities exposed to prolonged ERT after longstanding disease course. Extreme counterpart to cultured fibroblasts was represented by cardiocytes, postmitotic cells, modified by longstanding spontaneous storage.

This is also the first study focused on delivery of the applied $\alpha$-GALA into the storage cardiocytes which may contribute to better understanding of the factors responsible for the limited effectiveness of ERT in vivo.

\section{Patients}

For details of examined patients, their ERT regime, and the biopsy samples, see Table 1 .

\section{Materials and methods}

The study was approved by the Ethics Committee of the General Teaching Hospital and the First Faculty of Medicine, Charles University (60/2003F), Prague. Cardiac biopsy samples were taken during coronary surgeries. Written informed consent was obtained from patients included in the study.
Cell lines Four fibroblast cell lines of patients with classic type of Fabry disease (mutations in the GLA gene:p. Q280K, p.R342Q, c.801ins36, c.delEx2 (c.195-?-369+? del)) came from the cell culture depository of the Institute of Inherited Metabolic Diseases. Fibroblasts with mutations c.801ins36 and p.Q280K were from patient 1 and patient 2, respectively, who underwent heart biopsy later on. All cell lines (including p.R342Q and c.delEx2) were derived from skin biopsies taken several years before ERT from patients with classical form of the disease.

Recombinant $\alpha$-galactosidases A REPLAGAL (agalsidase alpha, a gift from Shire Human Genetic Therapies, Cambridge, MA, USA) sample no. 001-0229 was used without any further modification (dilution $1 \mathrm{mg} / \mathrm{ml}$ solution). FABRAZYME (agalsidase beta, a gift from Genzyme, Cambridge, MA, USA) batch no. H0214AM, diluted according to manufacturer's recommendation to $5 \mathrm{mg} / \mathrm{ml}$ and then further diluted to $1 \mathrm{mg} / \mathrm{ml}$ with redistilled water.

Experiments in cell cultures Cultured skin fibroblasts were grown in accordance with standard protocols in Dulbecco's modified Eagle's medium (DMEM) and 10\% bovine fetal serum (BFS).

Preparation of substrate The globoside, $\mathrm{Gb}_{4} \mathrm{Cer}$, was isolated from human erythrocyte membranes, characterized, and tritium-labeled at the ceramide moiety $(330 \mathrm{MBq} / \mathrm{mg})$. The $\left({ }^{3} \mathrm{H}\right) \mathrm{Gb}_{4} \mathrm{Cer}$ was incorporated into liposome particles (a mixture of phosphatidylcholine, $\alpha$-tocopherol, and phosphatidic acid, Sigma, Czech Republic) and coated with apoprotein E [2].

Feeding assays DMEM, $3 \mathrm{ml}$ per $25-\mathrm{cm}^{2}$ flask, with $1 \%$ BFS and radiolabeled glycolipid $\left(3.3 \times 10^{6} \mathrm{dpm} / 1 \mathrm{ml}\right)$ was applied to nearly confluent Fabry fibroblasts and incubated in a $5 \% \mathrm{CO}_{2}$ incubator for 3days [2].

Uptake of enzyme Three milliliters of the enzyme solution $(1.32 \mu \mathrm{g}$ of enzyme per milliliter, final activity $3.8 \mu \mathrm{mol}$ MU mg ${ }^{-1} \cdot \mathrm{h}^{-1}$, the same for both enzymes) were placed in fresh DMEM containing 10\% heat-inactivated BFS and applied to cells in $25-\mathrm{cm}^{2}$ flasks. The flasks were then incubated for different periods of time. At least two $25-\mathrm{cm}^{2}$ flasks were analyzed for each time period/enzyme combination $(0,12,24,48,96$, and $192 \mathrm{~h})$.

Analysis of $\left.{ }^{3} H\right) G b 3 C e r$ degradation Three milliliters of the enzyme solution $(0.66 \mu \mathrm{g}$ of enzyme per milliliter, final activity $1.9 \mu \mathrm{mol} \mathrm{MU} \mathrm{mg}{ }^{-1} \mathrm{~h}^{-1}$, the same for both enzymes) were placed in fresh DMEM containing $10 \%$ heat-inactivated BFS and conduritol B epoxide (final concentration $100 \mathrm{mM}$, Calbiochem-Novabiochem $\mathrm{GmbH}$, 
Table 1 Patients' data

\begin{tabular}{|c|c|c|c|c|c|c|c|c|}
\hline Patient & Age & Phenotype & $\begin{array}{l}\text { Mutation } \\
\text { in the } \\
G L A \text { gene }\end{array}$ & $\begin{array}{l}\alpha \text {-GALA activity }{ }^{\mathrm{c}} \text { in } \\
\mathrm{nmol} \mathrm{MU} \mathrm{\textrm {mg } ^ { - 1 }} \text { protein } \\
\mathrm{h}^{-1} \mathrm{WBC} \text { skin } \\
\text { fibroblasts }\end{array}$ & $\begin{array}{l}\text { Biopsy } \\
\text { before ERT } \\
\text { (year) }\end{array}$ & $\begin{array}{l}\text { Biopsy in the course } \\
\text { of ERT: Fabrazyme } \\
\text { (duration in months) }\end{array}$ & $\begin{array}{l}\text { LV mass }(\mathrm{g}) \\
\text { before ERT }\end{array}$ & $\begin{array}{l}\text { LV mass }(\mathrm{g}) \text { in } \\
\text { the course of ERT } \\
\text { (year of examination) }\end{array}$ \\
\hline 1 & $59^{\mathrm{a}}$ & Classical & c. 801 ins 36 & $0.19(0.4 \%) 0.63(1.3 \%)$ & $\begin{array}{l}\text { Skin } \\
\text { (1998) }\end{array}$ & $\begin{array}{l}\text { LV (6) saphenous v.(21) } \\
\text { heart auricle(21) biopsy } \\
\text { taken } 3 \text { days after last } \\
\text { infusion }\end{array}$ & $\begin{array}{l}440 \\
\text { (2002Jul) }\end{array}$ & $\begin{array}{l}472 \text { (2003Mar) } \\
817 \text { (2004Jun) } \\
910 \text { (2006Feb) } \\
840 \text { (2007May) }\end{array}$ \\
\hline 2 & $50^{\mathrm{a}}$ & Classical & p.Q280K & $0.13(0.3 \%) 0.95(1.9 \%)$ & $\begin{array}{l}\text { Skin } \\
(1980)\end{array}$ & $\begin{array}{l}\text { Heart auricle (65) skin }(65) \\
\text { skeletal muscle (65) biopsy } \\
\text { taken } 2 \text { days after last } \\
\text { infusion }\end{array}$ & $\begin{array}{l}338 \\
\text { (2001Jan) }\end{array}$ & $\begin{array}{l}404 \text { (2002Jun) } \\
340 \text { (2004Sept) } \\
423 \text { (2006Jan) } \\
583 \text { (2006Jun) } \\
521 \text { (2006Dec) }\end{array}$ \\
\hline 3 & $60^{\mathrm{b}}$ & Classical & p.H46Y & $0.14(0.3 \%)$ & - & - & ND & - \\
\hline
\end{tabular}

LV (left ventricle) mass was measured by echocardiography according to Sahn DJ et al., Circulation 58 (1978), pp 1072-1083.

Clinical details and ERT regime: Patient 1 underwent two coronary bypass graft surgeries (April 2003, June 2004). Patient 2 underwent coronary bypass surgery in November 2006. Both patients were treated by Fabrazyme (dosage, $1 \mathrm{mg} / \mathrm{kg}$ every 2 weeks); patient 1 since October 2002 and patient 2 since July 2002. Biopsy was taken on the third day after the protocolar infusion of Fabrazyme in patient 1 and on the second day after the infusion in patient 2. Patient 3 underwent renal transplantation in 1993 and was treated by ERT (Replagal $0.2 \mathrm{mg} / \mathrm{kg}$ every 2 weeks) for 3 years since September 2001. ERT was withdrawn 1 year before death because of advanced dementia.

$N D$ not determined

${ }^{\text {a }}$ Age when heart auricle biopsy was performed

${ }^{\mathrm{b}}$ Age at death. Only frozen autopsy samples of the heart were available for analysis which substituted approximate status without ERT.

${ }^{\mathrm{c}}$ Determined before ERT, control range for WBC 24.8-75.7 nmol MU mg ${ }^{-1}$ protein $\mathrm{h}^{-1} \quad(n=65)$; for skin fibroblasts $33.8-70.8 \mathrm{nmol} \mathrm{MU} \mathrm{mg}^{-1}$ protein $\mathrm{h}^{-1}(n=13)$

Germany) and applied to cells in $25-\mathrm{cm}^{2}$ flasks preloaded with $\left({ }^{3} \mathrm{H}\right) \mathrm{Gb}_{4} \mathrm{Cer}$ and incubated for different periods of time. Analyses were performed at least in two $25-\mathrm{cm}^{2}$ flasks for each time period/enzyme combination $(0,9,14$, 19 , and $24 \mathrm{~h})$.

Cell harvesting and homogenization The fibroblasts were harvested by trypsinization. The cell pellets were homogenized in distilled water in a cuphorn sonifier filled with ice for $3 \times 10$ s (Ultrasonic homogenizer 4710, Cole-Parmer, Chicago, IL, USA, 40\% output). Protein concentration [16], enzyme activities, and uptake of the $\left({ }^{3} \mathrm{H}\right) \mathrm{Gb}_{4} \mathrm{Cer}$ tracer were determined in homogenate aliquots.

Enzyme assay The activity of $\alpha$-GALA was assayed in culture medium and in cell and tissue homogenates according to the modified method of Mayes et al. [27]. Briefly, the reaction mixture contained $5 \mathrm{mM}$ of substrate, 4-methylumbelliferyl(MU)- $\alpha$-D-galactopyranoside (Sigma, Germany), in citrate buffer ( $\mathrm{pH} 4.5$ ). For cell and tissue homogenates, the reaction also contained $100 \mathrm{mM} \alpha-N$-acetylD-galactosamine to inhibit $\alpha-N$-acetylgalactosaminidase activity. The complete reaction mixture was incubated for $30 \mathrm{~min}$ at $37^{\circ} \mathrm{C}$, and the fluorescence of the released 4-MU was measured at excitation $365 \mathrm{~nm}$ and at emission $448 \mathrm{~nm}$ on a luminescence spectrometer (Perkin Elmer LS50B, Wellesley, USA).
Extraction and thin-layer chromatography analysis of $\left({ }^{3} \mathrm{H}\right)$ glycosphingolipids

The remaining cell homogenate was extracted with chloroform-methanol $(2: 1, v / v)$, and the lipids were separated on thin-layer chromatography (TLC) plates (Silica gel, Merck, Germany) using chloroform-methanolwater $(70: 30: 05, v / v / v)$ as the solvent system. Chromatograms were evaluated using a TLC linear radioactivity analyzer (Raytest, Germany) [2].

Immunofluorescence labeling Fibroblasts were grown on glass coverslips to near-confluence using standard methods. The cells were then grown for an additional $24 \mathrm{~h}$ in DMEM containing $10 \%$ of heat-inactivated BFS and $0.66 \mu \mathrm{g} / \mathrm{ml}$ of the recombinant enzyme.

For the experiments using mannose-6-phosphate (M-6P) receptor blocking, the M-6-P (Sigma, Germany) was added to the medium together with the enzymes to yield a final concentration $10 \mathrm{mM}$. Cells were fixed for $10 \mathrm{~min}$ in ice-cold methanol before immunodetection and nonspecific binding was blocked with 5\% BFS. Recombinant agalsidases were detected using rabbit polyclonal antibody against human $\alpha$-GALA TK88 (anti $\alpha$-GAL, TKT, Cambridge MA, USA) diluted to $9 \mu \mathrm{g} / \mathrm{ml}$, while cathepsin D was detected simultaneously using monoclonal mouse antibodies (Serotec, Oxford, UK) diluted to 
$20 \mu \mathrm{g} / \mathrm{ml}$. Gb3Cer was located using mouse monoclonal anti-Gb3 (CD77) antibody (BGR23, code 370680, Seikagaku, Japan) diluted to $6.7 \mu \mathrm{g} / \mathrm{ml}$ after $10 \mathrm{~min}$ fixation with $4 \%$ phosphate-buffered paraformaldehyde and blocking with $5 \%$ BFS. The primary antibodies were visualized using Alexa Fluor 488-conjugated goat anti-rabbit IgG, Alexa Fluor 488-conjugated goat antimouse IgG and Alexa Fluor 568-conjugated goat antirabbit IgG (Molecular Probes, Invitrogen, Carlsbad, CA, USA). The samples were examined using two Nikon confocal microscope setups (1) Nikon C1, Eclipse E800 microscope equipped with a laser scanning confocal head (Nikon, Japan) and a Nikon 60X, NA 1.4 oil immersion objective or (2 Nikon C1si LSM head mounted on TE-2000 inverted microscope and with Nikon TIRF NA $1.4960 \times$ oil immersion objective. All channels were recorded separately to avoid cross-talk between channels. The co-localization analysis was performed with representative images using ImageJ software [31] with JaCoP plugin [4] and Huygens image analysis software (SVI, Hilversum, The Netherlands). The degree of co-localization was assessed by coefficients described by Manders et al. [26]. Two independent experiments were done to support the results.

The image acquisition conditions were kept constant in all parameters for samples presented in Fig. 3e-h.

Histochemical and ultrastructural analyses of tissue samples Patient 1. The sample of superficial part of the left cardiac ventricle biopsied after 6months of ERT was processed for electron microscopy. Specimens of the heart auricle and part of the saphenous vein graft taken after 21 months of ERT were transferred to the liquid nitrogen and stored on dry ice.

Patient 2. Samples of the heart auricle, skin, and skeletal muscle taken after 65 months of ERT were frozen in liquid nitrogen or fixed with phosphate-buffered paraformaldehyde (Fluka, Buchs, Switzerland). Samples for standard ultrastructural analysis were fixed with $10 \%$ paraformaldehyde overnight, post-fixed in phosphate-buffered $1 \% \mathrm{Os} 0_{4}$, dehydrated and embedded into Epon-Araldit mixture. Samples for electron microscopic immunostaining were fixed with $4 \%$ paraformaldehyde for $2 \mathrm{~h}$, dehydrated, and embedded into LR White resin (London Resin Company, Reading, England). Skin biopsies taken before ERT start from both patients were processed for standard electron microscopy. Patient 3 (death one year after ERT termination). Postmortem frozen and resin embedded samples from the left cardiac ventricle were included into the study to substitute approximate status before ERT.

Cryostat sections were prepared from the frozen samples and used for immunohistochemical evaluation of the lysosomal storage status (Gb3Cer storage, lipopigment accumulation) for detection of the applied agalsidase protein and for histochemical evaluation of its activity.

Lysosomal storage status Gb3Cer storage was detected in cryostat sections after pretreatment with cold anhydrous acetone $\left(\right.$ at $4{ }^{\circ} \mathrm{C}$ ) for removal of possible apolar lipid admixture and for glycolipid fixation. They were briefly post-fixed with $4 \%$ buffered paraformaldehyde (for $5 \mathrm{~min}$ at $4^{\circ} \mathrm{C}$ ). After standard blockade of endogenous peroxidase (with sodium azide and $\mathrm{H}_{2} \mathrm{O}_{2}$ ) and non-specific proteinprotein interactions (with $5 \% \mathrm{BFS}$ ), the sections were incubated with monoclonal mouse anti-Gb3Cer antibody diluted $1: 100$ in $5 \% \mathrm{BFS}$ (at $37^{\circ} \mathrm{C}$ for $1 \mathrm{~h}$ or at $4^{\circ} \mathrm{C}$ overnight). Detection of bound primary antibody was achieved using EnVision + System-HRP Anti-Mouse (DakoCytomation, Glostrup, Denmark) and the DAB + Chromogen kit (K 3460, DAKO Cytomation, Carpinteria, USA). The staining specificity was checked using total lipid extraction by chloroform (C)-methanol (M)-water (W) 4:8:3, followed by C-M 2:1 (each step for 30min at room temperature). The sections were rinsed in methanol, briefly fixed in paraformaldehyde, and used for the lipid immunodetection. Lysosomal storage status was also studied by birefringence of liquid crystals of the stored polar lipid and by detection of lipopigment autofluorescence. The latter was evaluated by epifluorescence microscopy using the Nikon BV-2A filters blocks (EX 400-440, DM 455, BA $470)$. The best results were obtained after brief $(5 \mathrm{~min})$ preextraction of the lipids with $\mathrm{C}-\mathrm{M}$ mixture $(1: 1, v / v)$ to prevent moderate non-specific autofluorescence of the stored lipid. The liquid crystalline state of the stored lipid deposits exhibited considerable instability and was best evaluated using Baker's fixative solution. The results were compared with samples from age-matched controls. Neutral term lipopigment was used throughout the manuscript because of ambiguous terminology [34].

Immunohistochemical detection of the applied enzyme protein Cryostat sections were fixed with $4 \%$ phosphatebuffered paraformaldehyde exposed to standard blocking procedures (see above) and incubated for $1 \mathrm{~h}$ at $37^{\circ} \mathrm{C}$ with the primary polyclonal antibody TK 88 diluted to $4.5 \mu \mathrm{g} / \mathrm{ml}$ in 5\% FCS then washed in PBS and exposed to the detection kit (EnVision + System-HRP Anti-Rabbit, DakoCytomation). An alternative fixation of sections using a mixture of chloroform-acetone $(1: 1, v / v)$ for $30 \mathrm{~min}$ at room temperature followed by paraformaldehyde was used for some of the experiments. Semi-thin $0.5-\mu \mathrm{m}$ sections embedded into LR White medium were treated with citrate buffer pH6.0 for $40 \mathrm{~min}$ at $90^{\circ} \mathrm{C}$ and incubated after the aforementioned blocking procedures with TK 88 antibody for $1 \mathrm{~h}$ at $37^{\circ} \mathrm{C}$ and thereafter treated with the detection kit as described above. 
The sections immunostained either for Gb3Cer or for $\alpha$-GALA were counterstained with Harris hematoxylin and mounted into the Immu-Mount medium (Shandon, Pittsburgh, PA, USA) which allowed simultaneous evaluation of the presence of the applied enzyme (eventually Gb3Cer), birefringent lipid and autofluorescent lipopigment.

Histochemical detection of in situ enzyme activities Activity of $\alpha$-GALA was evaluated using both the post-coupling technique with 6-bromo-2-naphthyl- $\alpha$-D-galactopyranoside (LaChema, Brno, Czech Republic) and Fast Blue B and the simultaneous azo-coupling technique with 1-naphthyl$\alpha$-D-galactopyranoside (Koch Light, Colnbrook Bucks, UK) and hexazonium pararosaniline; both were done on semi-permeable membranes allowing to detect activities of both bound and soluble enzymes according to the published prescriptions [24]. Semi-permeable membrane technique was used for demonstration of activities of $\beta$-galactosidase (indigogenic method), $\beta$-glucuronidase, and acid phosphatase (simultaneous azo-coupling method using in both cases naphthol ASBI-type substrates and hexazonium pararosaniline). Acid phosphatase activity was also demonstrated using the aqueous medium [24].

Mannoso-6-phosphate receptor (MPR, cation-independent) was detected using monoclonal antibody (2G11 clone, Abcam, Cambridge, UK), diluted 1:400. Polyclonal antibody against cathepsin D was purchased from DAKO and used in dilution 1:200. In both cases, the incubation was overnight at $4^{\circ} \mathrm{C}$.

\section{Results}

Studies in cultured mutant cells

\section{Uptake of recombinant enzymes into cultured Fabry cells and efficiency of Gb3Cer hydrolysis}

To monitor the function of agalsidases in situ, the uptake into Fabry fibroblasts was measured over the course of $192 \mathrm{~h}$ (8days). Both enzymes were similarly internalized into the cultured cells, with maximum activity at $24 \mathrm{~h}$ incubation. The uptake of agalsidase beta measured with MU-substrate was 2.5-fold greater than that of agalsidase alpha, although the enzymes were applied at the same concentration $(1.32 \mathrm{mg} / \mathrm{ml}$ medium). This result was confirmed by repeated experiments on three different Fabry fibroblast cell lines. After $24 \mathrm{~h}$, the cellular activities of both enzymes started to decline. However, even after 8days, the values exceeded several times the normal activity of healthy cells (Fig. 1). Activity in the culture medium decreased equally in both agalsidases, falling to $4-6 \%$ of its original value (Fig. 1, inner graph).

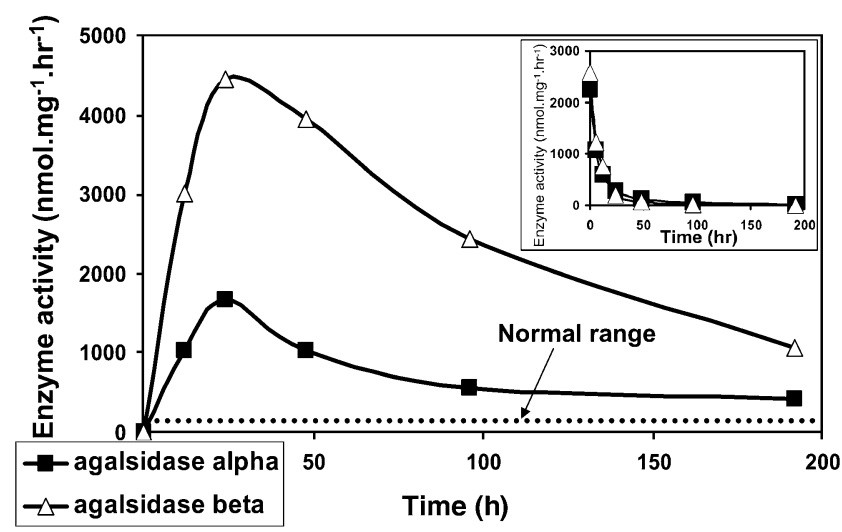

Fig. 1 Internalization of recombinant $\alpha$-galactosidases $\mathrm{A}$ (agalsidases alpha and beta) into Fabry skin fibroblasts as a function of time. Recombinant enzymes $(1.32 \mu \mathrm{g}$ of enzyme protein per milliliter of medium) were applied into cultures of Fabry cells incubated under standard conditions. After 0, 12, 24, 48, 96, and $192 \mathrm{~h}$, medium was removed, cells harvested, and analyzed in vitro with MU-substrate as described in "Materials and methods". Each value is average of duplicate flasks. Intracellular agalsidase beta activity exceeded 20 times normal levels at the maximum $(24 \mathrm{~h})$, while agalsidase alpha activity was eight times the normal value in healthy cells $(50.3 \pm$ $13.6 \mathrm{nmol} \mathrm{MU} \mathrm{mg}{ }^{-1}$ protein $\mathrm{h}^{-1}$ in controls, see broken line). Insert is a time course of agalsidases stability in the culture medium

The correction of the defect in Fabry cells was monitored with natural substrate in mutant cell cultures pre-loaded with tritium-labeled globoside $\left({ }^{3} \mathrm{H}\right) \mathrm{Gb}_{4} \mathrm{Cer}$, the $\left({ }^{3} \mathrm{H}\right) \mathrm{Gb}_{3} \mathrm{Cer}$ precursor. The quantity of degradation products calculated from TLC-radioactivity scans reflected approximately the uptake tendencies of the respective enzymes (Fig. 2). Despite the differences in uptake (Fig. 1), both loaded agalsidases proved efficient in intra-lysosomal degradation of $\mathrm{Gb}_{3} \mathrm{Cer}$.

\section{Confocal microscopic examination of internalized}

agalsidases with endosomal/lysosomal markers in cultured Fabry cells

Fabry fibroblasts were incubated with recombinant agalsidases for 24h. The intracellular distribution of agalsidase alpha and agalsidase beta in the cells was detected by anti $\alpha$-GALA antibody (red channel, Fig. 3a,b). The lysosomes were visualized in the perinuclear region by immunodetection of cathepsin D (green channel, Fig. 3a,b). In a similar manner, the localization of intracellular Gb3Cer deposits was correlated with recombinant enzymes internalized into $\alpha$ GALA deficient fibroblasts (Fig. 3g,h). The merger of the agalsidase and cathepsin D signals suggested lysosomal localization of loaded recombinant enzymes and was further documented by co-localization maps (Fig. 3c,d). Correlation of agalsidase signal with lysosomal transmembrane protein LAMP 2 was also demonstrated (data not shown).

Endogenous enzyme protein was not detected in the cells of Fabry patients (data not shown). The addition of M-6-P to the culture medium, together with agalsidases, strongly 


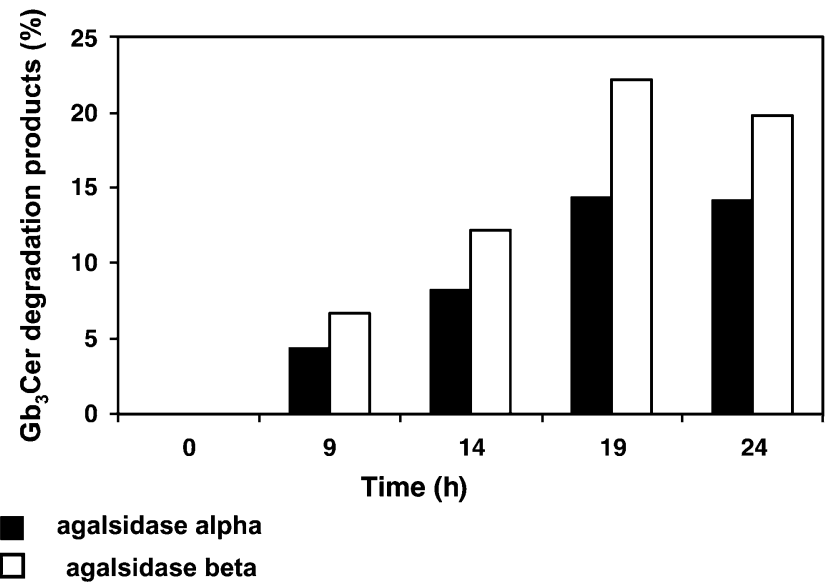

Fig. 2 Degradation of $\left({ }^{3} \mathrm{H}\right) \mathrm{Gb}_{3}$ Cer by Fabry fibroblasts loaded with $\left({ }^{3} \mathrm{H}\right)$-globoside after application of agalsidases alpha and beta. Illustration of 24-h experiments (example of one experimental set from three is shown). $\left({ }^{3} \mathrm{H}\right)$-globoside $\left(5 \times 10^{6} \mathrm{dpm}\right)$, precursor of $\left({ }^{3} \mathrm{H}\right)$ $\mathrm{Gb}_{3} \mathrm{Cer}$, was incorporated into the liposomes coated with Apo E and added to the culture medium as described in "Materials and methods". After 3 days of incubation, the agalsidases were applied at final activity of $1.9 \mu \mathrm{mol} \mathrm{ml}^{-1} \mathrm{~h}^{-1}$. After $0,9,14,19$, and $24 \mathrm{~h}$, cells were harvested, the lipids extracted, separated by high performance thin layer liquid chromatography, and the products were quantified by TLC linear radioactivity analyzer ("Materials and methods"). Percentage of degradation products was calculated from TLC scans in relation to total cell radioactivity comprising substrate $\left({ }^{3} \mathrm{H}\right) \mathrm{Gb}_{3} \mathrm{Cer}$ and the sum of its degradation products partially transformed into products of resynthesis (phospholipids)

inhibited the uptake of both enzymes (Fig. 3e,f), confirming that M-6-P receptor endocytosis is a major pathway of agalsidase transport into fibroblasts. The double labeling of Gb3Cer (Fig. 3g,h, green channel) and recombinant enzymes (Fig. 3g,h, red channel) did show only a few granular structures containing non-degraded Gb3Cer which were still present. The co-localization map of Gb3Cer and recombinant enzymes (Fig. 3i,j) showed only limited overlap (compare logarithmically color coded overlap coefficient in co-localization maps of $\mathrm{Gb} 3 \mathrm{Cer} / \alpha$-GALA and $\mathrm{CatD} / \alpha$-GALA).

Studies in tissues

\section{In vitro $\alpha$-GALA activity in the heart samples}

$\alpha$-GALA activity determined in the auricular sample of the patient 1 was 1.53 vs. $10.18 \pm 2.32 \mathrm{nmol} \mathrm{MU} \mathrm{mg}{ }^{-1}$ protein $\mathrm{h}^{-1}$ in controls $(n=5)$. This value represented $15 \%$ of the normal activity of the enzyme in the auricular part of the heart which implies slight increase from deficient values. There was no representative sample of the heart auricle in patient 2 for biochemical analysis. Residual enzyme activity in the autopsy sample (patient 3) was barely detectable $\left(0.12 \mathrm{nmol} \mathrm{MU} \mathrm{mg}{ }^{-1}\right.$ protein $\mathrm{h}^{-1}$, i.e., about $1 \%$ of the control mean).

\section{Immunohistochemical and ultrastructural studies}

Evaluation of the lysosomal storage status Before ERT, dermal capillaries (skin biopsy available in patients 1 and 2) displayed lysosomal storage (Fig. 4a). ERT led to complete clearance of the capillary endothelium lysosomes already after 6 months (patient 1) from the stored lipid and to retraction of the originally expanded system to normal dimensions (Fig. 4b,c). Capillary basement membranes were thin and single. Capillary endothelial storage in various degrees was detectable in the postmortem heart specimen of the patient who died 1 year after ERT withdrawal (Fig. 4d).

The auricular cardiocytes in both patients on ERT displayed variable, but on average high degree, Gb3Cer storage concentrated in the large perinuclear region (Fig. 5a). Lipid storage was paralleled by increase in lipopigment (Fig. 5c). Cardiocytes free of lysosomal lipid storage and containing only lipopigment were rare, and those free of both lipid and lipopigment were exceptional. The postmortem heart specimen displayed massive and uniform lipid storage occupying the bulk of the cardiocyte cytoplasm (Fig. 5b). Lipopigment was present in the form of dispersed tiny granules (Fig. 5d). Ultrastructure of cardiocytes, studied in all three cases, showed numerous lysosomes with varying degrees of aggregation and fusion with deposits of loosely or densely packed lipid mem-

Fig. 3 Co-localization of internalized agalsidase alpha (a-i) and agalsidase beta $(\mathbf{b}-\mathbf{j})$ with cathepsin D and Gb3Cer in the Fabry fibroblasts after 24-h incubation (a, b) Confocal analysis of cells labeled for $\alpha$-galactosidase A ( $\alpha$-GALA, red) and intra-lysosomal marker cathepsin D (CatD, green) displayed granular distribution of both signals and their parallel considerable overlap. Mander's coefficients $M_{\mathrm{GAL}}$ and $M_{\mathrm{CatD}}$ ranged from 0.209 to 0.441 and 0.53 to 0.849 in the images, respectively. $M_{\mathrm{GAL}}$ and $M_{\mathrm{CatD}}$ coefficients represent the fraction of co-localizing pixels from the overall number of pixels with intensity values above the given threshold calculated for the particular image channel. Threshold levels to filter background were set to $10 \%$ of the pixel intensity range in both channels. The colocalization of both signals is also illustrated by co-localization maps (c, d) employing overlap coefficient values $(0-1)$, color coded by lookup table placed under this panel. Addition of $5 \mathrm{mM}$ of M6P to the culture medium completely blocked the $\alpha$-GALA transport to the lysosomes $(\mathbf{e}, \mathbf{f})$ and changed the signal of $\alpha$-GALA from granular (intra-lysosomal) pattern to diffuse low-intensity signal virtually inseparable from nonspecific background. The co-labeling of $\alpha$ GALA and Gb3Cer in the cultured fibroblasts of Fabry patients incubated $24 \mathrm{~h}$ with recombinant agalsidases showed very limited overlap $(\mathbf{g}, \mathbf{h})$. The distribution of co-localization of both signals is also demonstrated by co-localization map of overlap coefficient $(\mathbf{i}, \mathbf{j})$. Comparing images $(\mathbf{g}, \mathbf{h})$ and $(\mathbf{i}, \mathbf{j})$ demonstrates minimal correlation of $\alpha$-GALA and Gb3Cer signals in the cells. This observation suggests that the population of lysosomes with strong $\alpha$-GALA detection has already been cleared off Gb3Cer. Scale bars in $\mathbf{f}$ (valid for $\mathbf{e}, \mathbf{f}$ ) and $\mathbf{j}$ (valid for $\mathbf{a}-\mathbf{d}$ and $\mathbf{g}-\mathbf{j}$ ) correspond to $10 \mu \mathrm{m}$ 

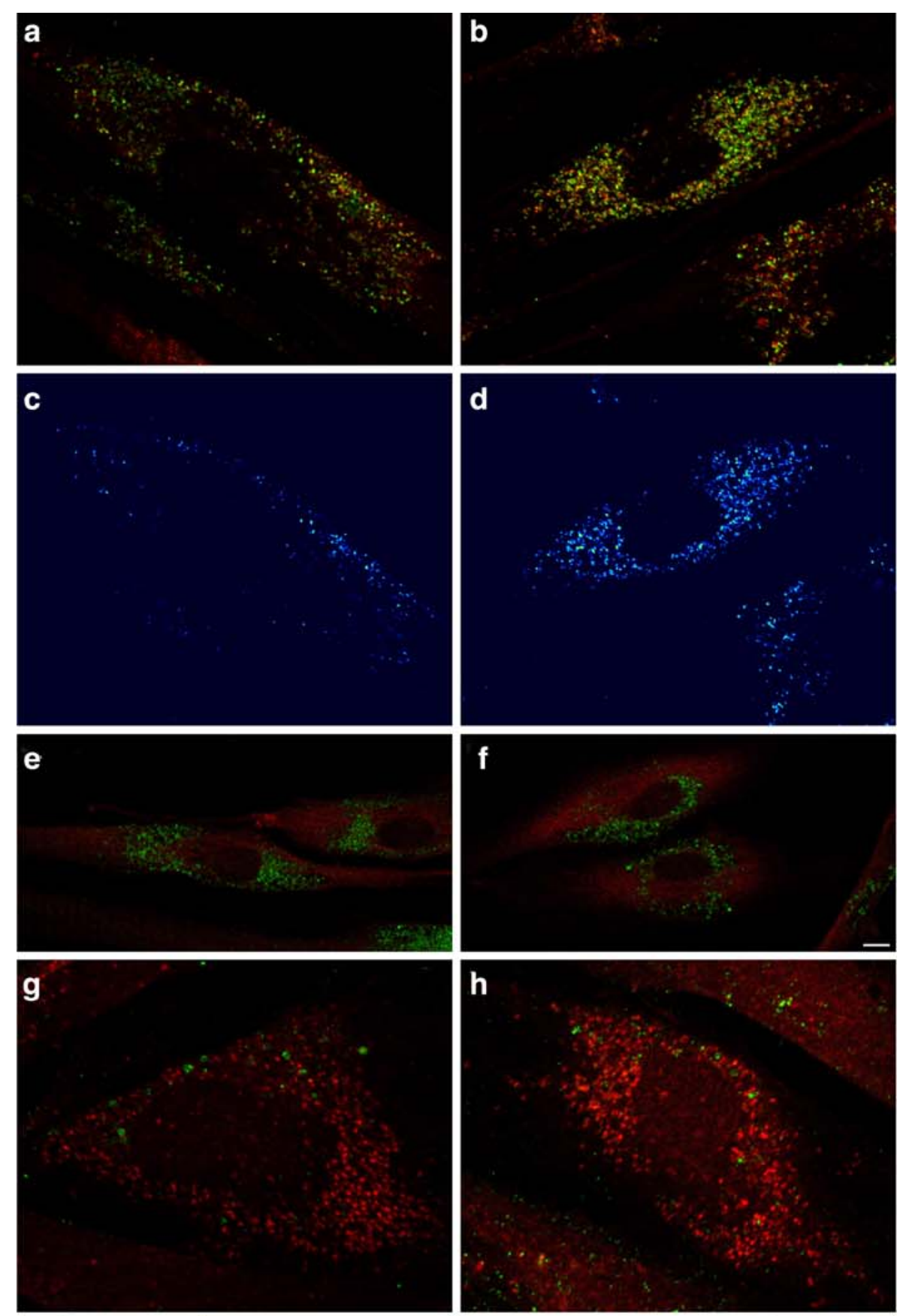

d
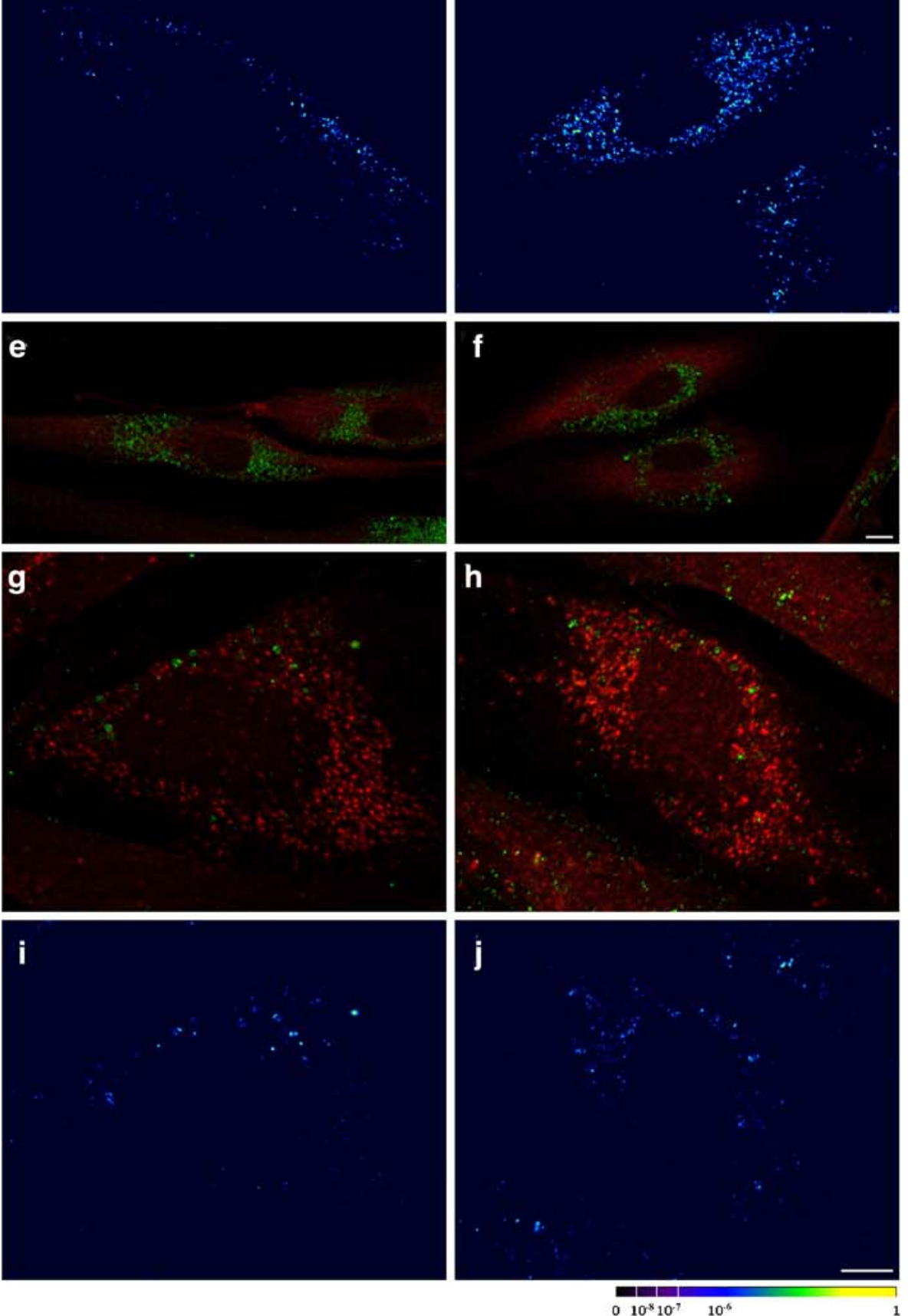


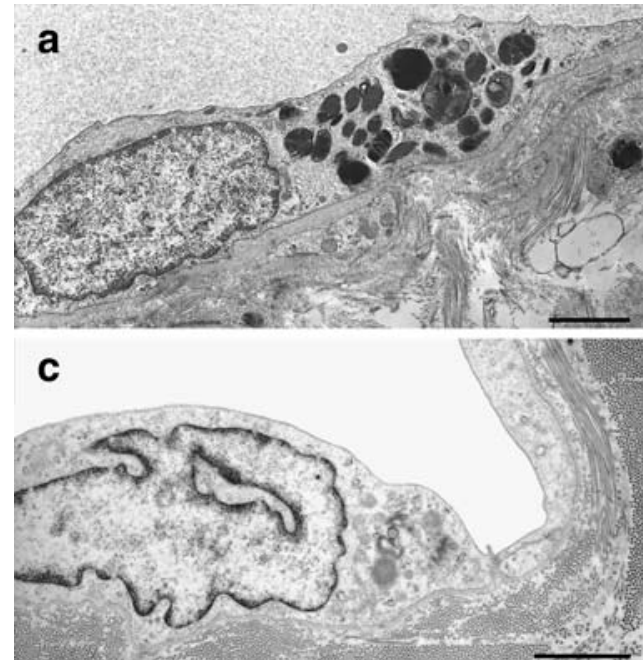

Fig. 4 Ultrastructure of the storage in the heart capillary endothelium. a Capillary endothelium with prominent storage before ERT. Patient 2 (bar $2 \mu \mathrm{m}$ ). b Capillary endothelium free of storage after 65 months of ERT. Persisting storage in pericapillary cells. Patient 2 (bar $4 \mu \mathrm{m})$. c Detail of the capillary endothelium after 6 months of ERT with

branes often mixed with pleiomorphic lipopigment deposits (Fig. 6a). In patient 2, there were exceptional cardiocytes with discrete lysosomal lipid storage but with numerous small lucent vesicles, suggesting relatively effective lysosomal clearance (Fig. 6b).

In all cases, irrespective of the ERT, the vascular smooth muscle cells displayed marked lipid storage. Persistent storage was seen in the skin eccrine glands (Fig. 7a) in pericytes and stromal fibroblasts, especially those in the hair bulb matrix (Fig. 7b). Discrete storage was found in the skeletal muscle fibers (not shown here). In the sample of the saphenous vein graft, there was prominent lipid storage in intimal cells and in the smooth muscle cells of the tunica media (Fig. 7c), which also displayed hypertrophy and hyperplasia. Endothelial cells of the tunica intima were free of storage, as were the endothelial cells of the adventitial vessels.

Storage in some cell types was accompanied by increase in lipopigment (mostly in the cardiocytes, skeletal muscle, but almost absent in the smooth muscle cells). Electron microscopy showed densely packed lipid membranes and pleiomorphic structure of the lipopigment in lysosomes.

Evaluation of the intracellular delivery of the applied enzyme In situ immunodetection of the applied enzyme performed in heart samples of the ERT-treated patients showed relatively strong signal of variable intensity in a majority of cardiocytes (Fig. 8a). Simultaneous detection of both the immunostained agalsidase protein and the stored birefringent lipid/lipopigment in a single section showed the coexistence of both the targeted enzyme and lipid

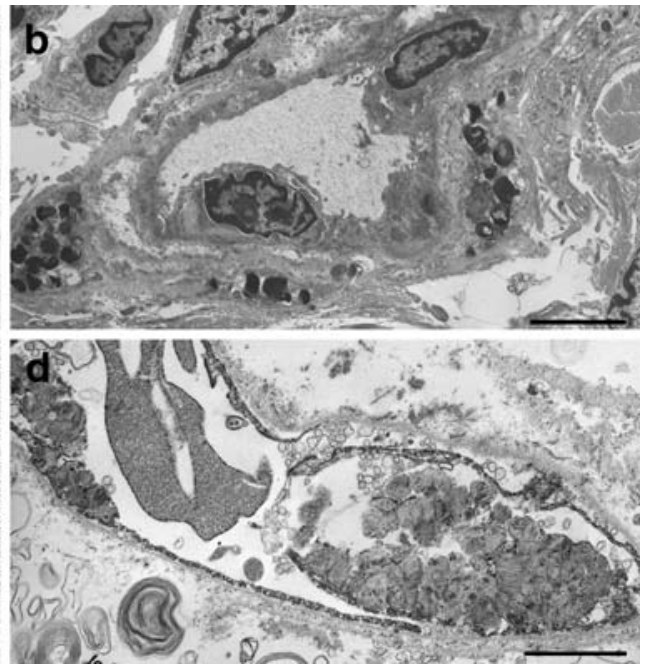

discrete lysosomal system containing unspecific lipopigment. Patient 1 (bar $2 \mu \mathrm{m}$ ). d Lysosomal storage in the capillary endothelium of the heart after 1 year of ERT termination. This picture represents extreme in the wide range of capillary storage levels. Patient 3 (bar $2 \mu \mathrm{m}$ )

storage in a very close contact in the majority of cardiocytes (Fig. 8c). More intimate contact between the targeted enzyme and the storage compartment was seen after brief extraction of the stored lipid with chloroform-acetone mixture (see "Materials and methods"; Fig. 8d). Unfortunately, the applied enzyme proved to be fixation sensitive, so that our attempts to define its relation to the storage compartment at the ultrastructural level failed. However, in semi-thin sections exposed to intensive antigen retrieval, there were numerous positive granules of the applied enzyme interspersed between autofluorescent lipopigment granules (Figs. 8e,f). Both enzyme histochemical techniques (see "Materials and methods") showed the presence of active enzyme in the storing cardiocytes (Fig. 9a). There was also a close relation of the enzyme product to the storage lysosomal compartment better seen in simultaneous azo-coupling technique. Strong immunohistochemical signal for the enzyme protein was seen in the vascular and endocardial endothelium and in the epicardial mesothelium in both patients on ERT. Neither the enzyme protein nor its activity was detectable in cardiocytes in the Fabry postmortem heart sample without ERT (patient 3; Figs. 8b, 9b).

Other lysosomal enzymes in the cardiocytes The storage atrial cardiocytes displayed strong and uniform induction of acid phosphatase activity (Fig. 10a). In contrast, induction of $\beta$-galactosidase activity was highly irregular (Fig. 10b). Activity of $\beta$-glucuronidase was barely detectable. Activities of the above enzymes in autopsy samples were uniformly low. 

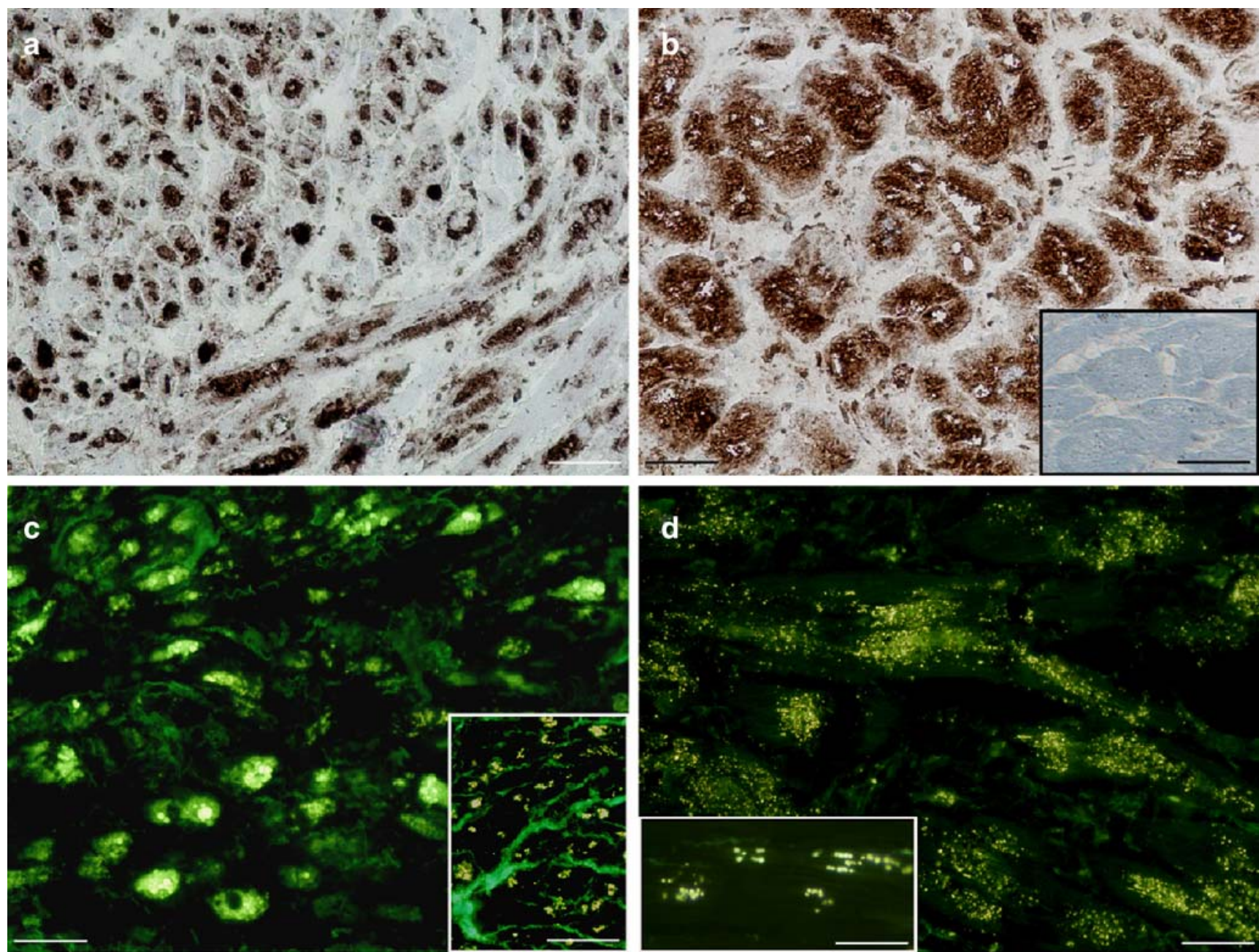

Fig. 5 Persisting lipid storage in cardiocytes. a, b Immunohistochemical demonstration of Gb3Cer. a Cardiocytes of the heart auricle (patient 2) after 65 months of ERT (bar $100 \mu \mathrm{m}$ ). b Cardiocytes of the left ventricle. Autopsy (patient 3) 1 year after ERT cessation. Insert shows absence of Gb3Cer staining in control cardiocytes (bars $100 \mu \mathrm{m})$. Note certain degree of variability of storage, reflecting parallel excessive lipopigment deposition. c, d Increase of the

autofluorescent lipopigment demonstrated after brief lipid extraction with $\mathrm{C}-\mathrm{A}$. c Large lipopigment clusters in heart auricle cardiocytes (patient 2). Insert: age-matched control (bars $100 \mu \mathrm{m}$ ). d Cardiocytes in the left ventricle (patient 3) with dispersed numerous discrete lipopigment granules (bar $100 \mu \mathrm{m}$ ). Insert: age-matched control showing coarser lipopigment granules restricted to the perinuclear region (bar $50 \mu \mathrm{m})$

Signals of both MPR (Fig. 10c) and cathepsin D (not shown) in the biopsy samples were remarkably heterogeneous in storage cardiocytes ranging from barely detectable to very strong intensities.

\section{Discussion}

Studies in cell culture Higher uptake of beta- than alphaagalsidase reflected greater number of phosphorylated

Fig. 6 Ultrastructure of the cardiocyte storage. a Patient 2.

Atrial cardiocytes after

65 months of ERT with numerous individual lysosomes accumulating lipid dominating over lipopigment (bar $2 \mu \mathrm{m})$. b Exceptional finding in the same patient showing only discrete lipid storage lysosomes. There are numerous small vesicles with lucent content, which most probably represent cleared lysosomes $($ bar $2 \mu \mathrm{m})$
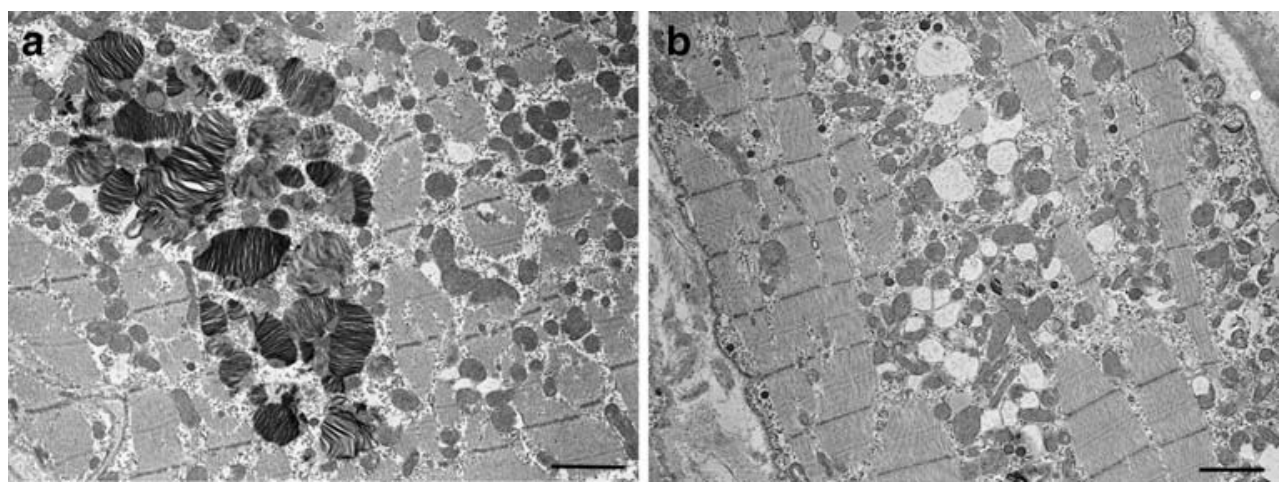

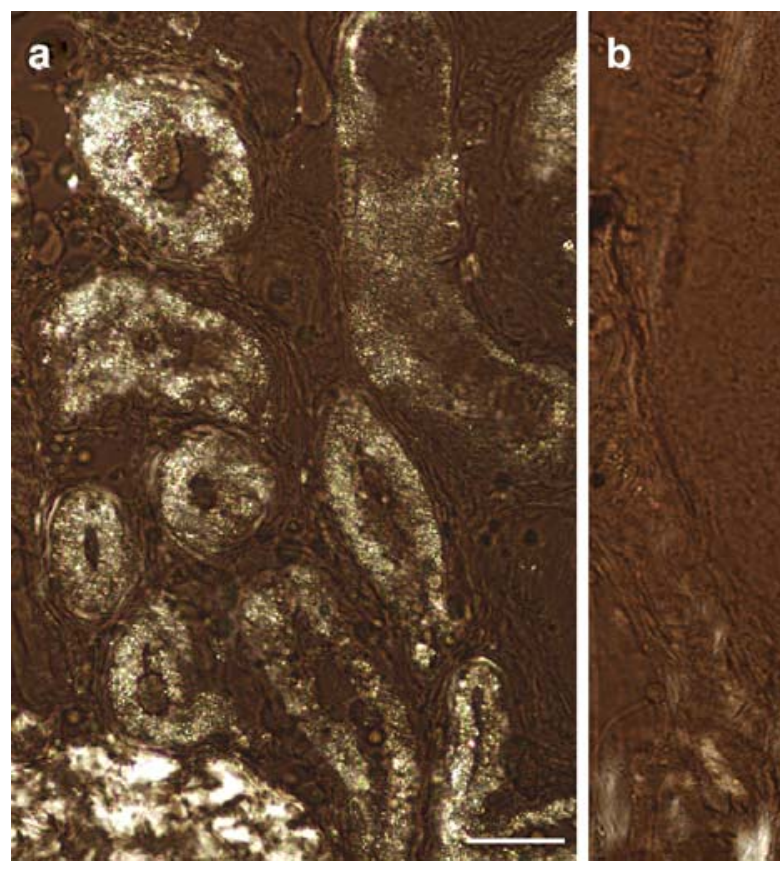

Fig. 7 Persisting storage in other cell types. a, b Patient 2 (ERT 65 months). Birefringent stored lipid in eccrine skin glands (a) (bar $100 \mu \mathrm{m})$ and in hair follicle matrix fibroblasts (b) (bar $50 \mu \mathrm{m})$. c
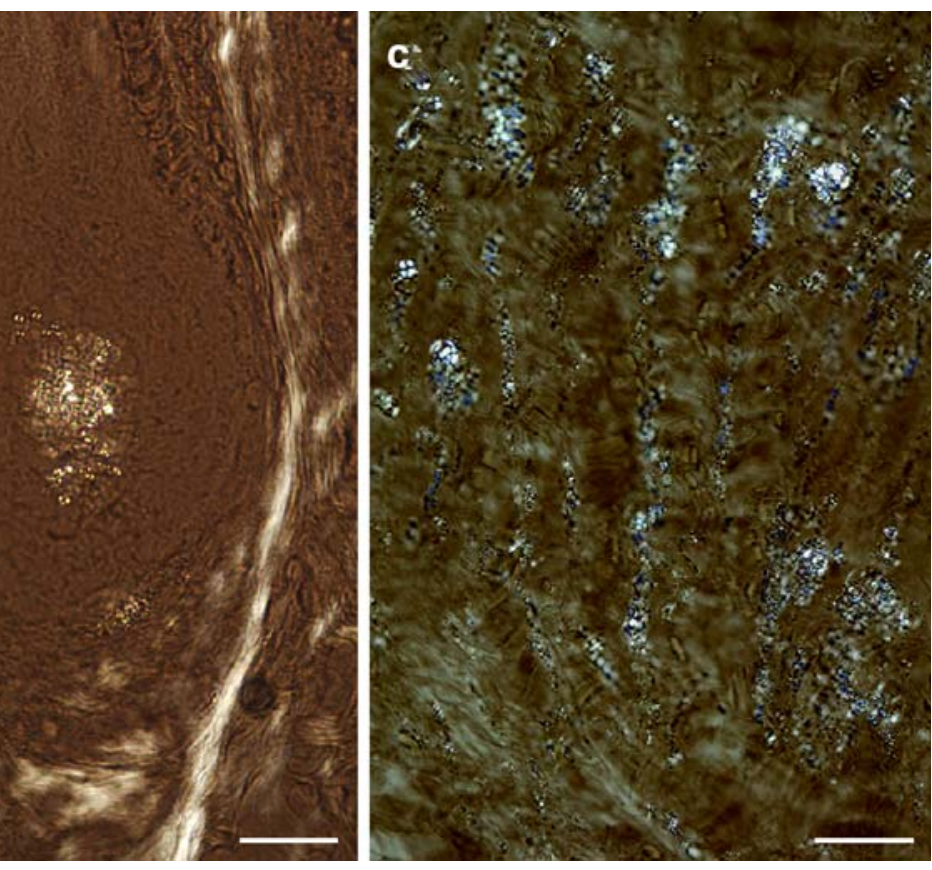

Patient 1 (21 months on ERT). Graft of saphenous vein used for coronary artery reconstruction with massive birefringent deposits of the stored lipid (bar $100 \mu \mathrm{m})$ mannose moieties per beta enzyme molecule [23, 33] and presumed principal role of MPR-mediated endocytosis [18] in skin fibroblasts which are receptor-rich. The complete inhibition of cellular uptake of both agalsidases by M-6-P is in accord with this conception.

Lysosomal targeting of the applied active enzyme was double-checked. Firstly, successful targeting of enzyme therapeutics to lysosomes has been proven through colocalization with lysosomal marker cathepsin D. Evaluation of images based on calculation of correlation and colocalization coefficients pointed to slightly lower colocalization parameters for the alpha compared to the beta enzyme.

It must be pointed out that enzyme endocytosis and trafficking via early to late endosomes is a dynamic process. Therefore, only partial co-localization with lysosomal markers can be achieved under the condition of continuous enzyme supply. Final evaluation of Gb3Cer and $\alpha$-GALA signals in Fig. 3i,j strongly suggested that lysosomes in fibroblast population were almost cleared of substrate after 24-h incubation with any of the enzymes.

Secondly, the delivered enzyme was shown to degrade efficiently the natural substrate $\left({ }^{3} \mathrm{H}\right) \mathrm{Gb}_{3} \mathrm{Cer}$ produced directly in lysosomes from its radiolabeled precursor $\left({ }^{3} \mathrm{H}\right)$ $\mathrm{Gb}_{4} \mathrm{Cer}$. The exact quantification of lysosomal $\left({ }^{3} \mathrm{H}\right) \mathrm{Gb}_{3} \mathrm{Cer}$ degradation in situ confirmed indirect observation that recombinant agalsidases degrade accumulated $\mathrm{Gb} 3 \mathrm{Cer}$ in a dose-dependent manner [33].
In situ $\left({ }^{3} \mathrm{H}\right) \mathrm{Gb} 3 \mathrm{Cer}$ degradation revealed lower differences between the two enzymes than in vitro assay with soluble MU-analog using the whole homogenate of agalsidase-loaded fibroblasts. This may be related to the intracellular transport and unspecified location of agalsidase in in vitro assay and to the availability of Sap B in lysosomes when supply of enzyme is high.

However, despite the different degree of agalsidase endocytosis, the cell-associated activity of both enzymes exceeded by several times the $\alpha$-GALA activity of normal healthy cells (see Fig. 1), and both were found effective in cleavage of $\left({ }^{3} \mathrm{H}\right) \mathrm{Gb}_{3} \mathrm{Cer}$. Their stability in the medium was found identical in accordance with findings in blood plasma [33].

Our experiments demonstrated effective targeting of the applied enzyme to fibroblast lysosomes using both colocalization and cleavage of its substrate locally produced from its exogenously added precursor. $\left({ }^{3} \mathrm{H}\right) \mathrm{Gb}_{4} \mathrm{Cer}$ was used for the first time as an intra-lysosomal tracer of function of recombinant agalsidases that does not increase the substrate load and can serve as a model system for evaluation of catabolic lysosomal functions and their defects.

To sum up, the ERT is effective in the cultured fibroblast system. In our view, it is because Fabry fibroblasts represent a short-lived dynamic cell population unmodified by low degree of spontaneous storage. Such cells exposed transiently to a trace amount of labeled substrate can effectively endocytose the recombinant enzyme. The 

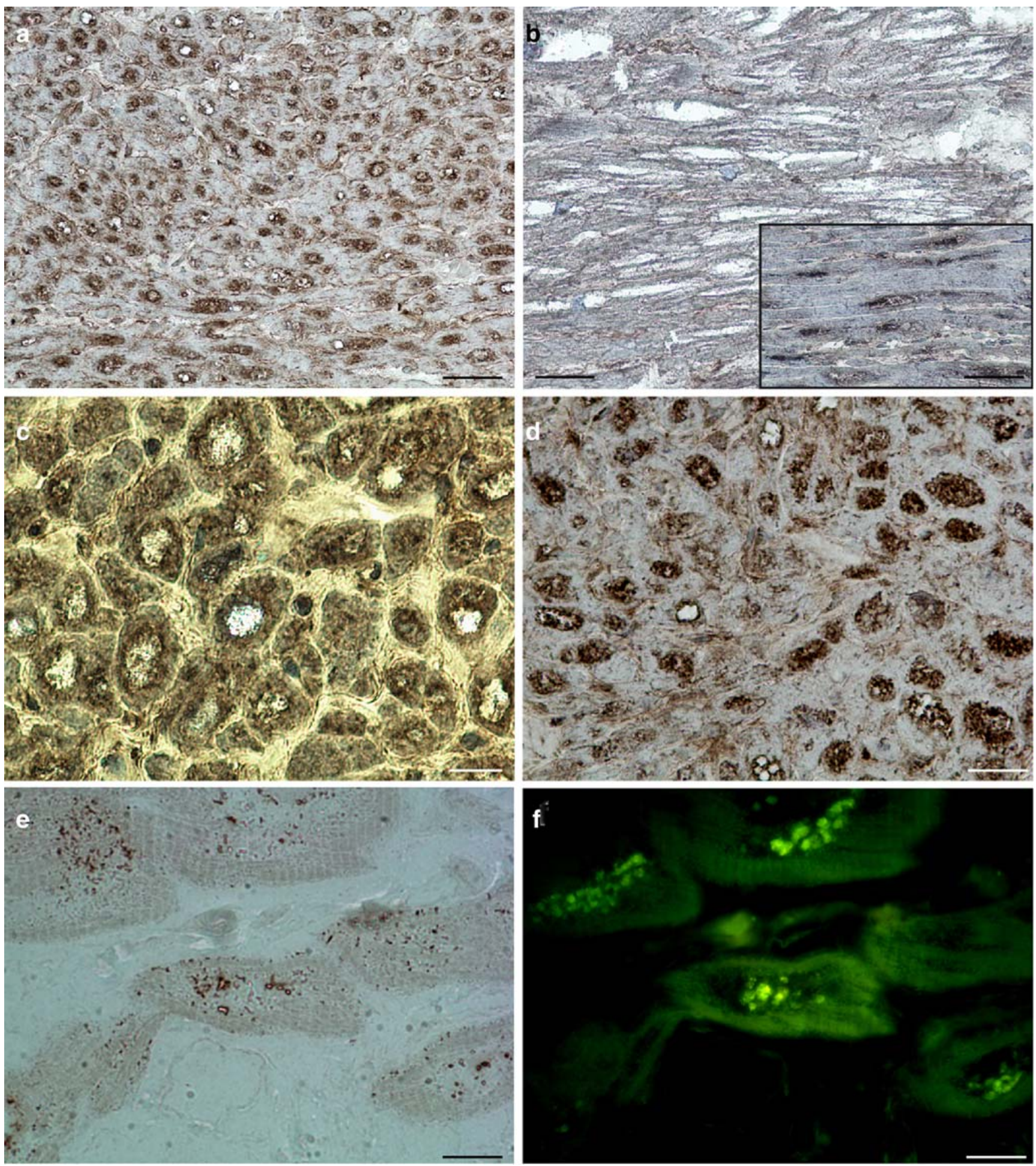

Fig. 8 Immunohistochemical detection (TK 88 antibody) of $\alpha$-GALA protein in cardiocytes. a Strong signal for the enzyme protein in atrial cardiocytes in patient 1 ( 21 months on ERT; bar $100 \mu \mathrm{m})$. b Absence of signal in ventricular cardiocytes in patient 3 (1 year after ERT withdrawal). Insert: signal for endogenous $\alpha$-GALA in control ventricular cardiocytes (bars $100 \mu \mathrm{m}$ ). c Simultaneous immunohistochemical detection of the enzyme and of the birefringent stored lipid showing coexistence of both in same cells. Semi-crossed Nicols (bar

$30 \mu \mathrm{m})$. d Immunohistochemical detection of the enzyme after brief lipid pre-extraction shows close relation of the enzyme to the storage compartment (bar $50 \mu \mathrm{m}$ ). e Immunohistochemical detection of the enzyme in a semi-thin section of LR-White-embedded specimen (bar $20 \mu \mathrm{m}$ ). f The stained section was simultaneously examined under UV to show lipopigment (unstained) which represents marker of the storage compartment (bar $20 \mu \mathrm{m}$ ). c, d Patient 1; e, f patient 2 


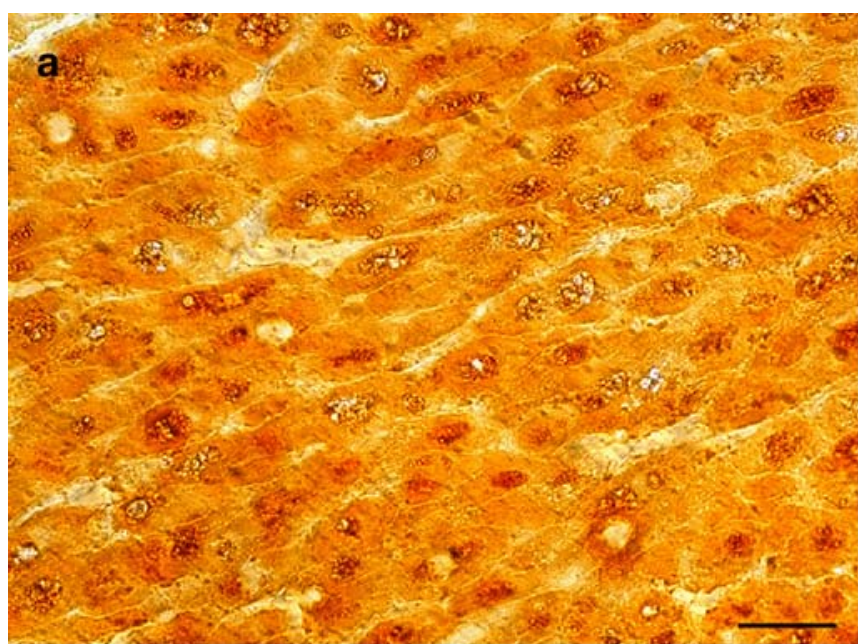

Fig. 9 Histochemical evaluation of $\alpha$-GALA activity with simultaneous azo-coupling method. a Presence of enzyme activity in storing atrial cardiocytes of patient 1 (21 months on ERT; bar $100 \mu \mathrm{m})$.

enzyme is delivered to the storage compartment where it exerts its degradative function. The whole process is facilitated by easy access to the applied enzyme via MPR and by the possibility to endocytose it along the entire cell perimeter of unpolarized cell.

Studies in tissues Our study showed effective clearing of endothelial cells by ERT corresponding to the published results $[21,7,36]$. The design of our study allows us to conclude that endothelial storage is resumed within 1 year after cessation of ERT. In the Fabry disease mouse model, the storage was resumed after several weeks of withdrawal of the enzyme [21].

In contrast to endothelia, the storage persisted in a set of cells despite the continuous ERT, e.g., in cardiocytes, vascular smooth muscle cells, pericytes, some fibroblasts, and perineurial cells, all repeatedly described to resist substantial storage reduction by ERT [12, 40, 7, 39, 43, 32, $33,36]$. We may add skin eccrine glands, hair bulb fibroblasts, and skeletal muscle. The design of the study did not allow detecting possible diminution of the persisting storage mentioned in some of the above-quoted reports. For instance, the cardiocyte storage pattern in both our cases admits partial clearance (Fig. 6b). Persistent storage in cardiocytes was accompanied by a notable increase in lipopigment which should be taken as irreversible. These findings may explain the absence of cardiac improvement in either patient on ERT (see Table 1).

It is not easy to explain the limited ERT effectiveness. There is the undisputed role of the physical barriers, represented by fibrous stroma and basal membranes, especially when multiplied around capillaries [11]. Free access of the applied enzyme to endocytotically active cell perimeter in non-polarized cultured fibroblasts and through

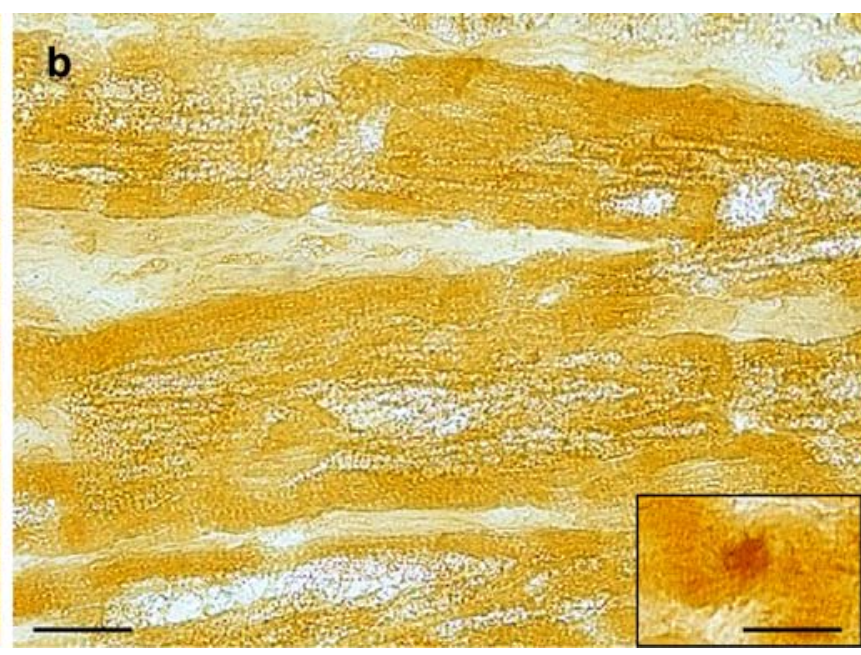

Compare with Fig. 8. b Absence of enzyme activity in ventricular cardiocytes 1 year after cessation of ERT (patient 3). Insert shows enzyme activity in control ventricular cardiocyte (bars $50 \mu \mathrm{m}$ )

fenestration in the liver sinusoidal endothelium to the hepatocyte basolateral pole may contribute significantly to the effective ERT [35] (also M.E. personal observation), similarly as the number of MPR known to be of high density in fibroblasts $[42,18]$. However, the density of the latter was not shown to correlate with the level of the applied enzyme uptake [29]. In polarized storage cells (epithelia, e.g., in the sweat glands, respiratory epithelium, etc.), the applied enzyme uptake is restricted to the basolateral pole. In case of renal tubules, both poles may participate to different degree in various parts of the nephron [38]. In the case of endothelial cells, the reproducible effectiveness of ERT may be explained by the barrierless access of the enzyme to the apical pole active in endocytosis [37].

Our findings point to further potentially important facts. Before all, it is the presence of the applied active enzyme inside the storage cardiocytes in patients under ERT (not in samples from patient 3 with ERT terminated). We base this crucial finding on the following data. No enzyme protein was immunohistochemically detectable in cultured mutant fibroblasts of both patients. As the value of enzyme activity in wild-type fibroblasts is much higher (approximately fivefold) than in the heart, it excludes presence of detectable amount of endogenous mutant enzyme in atrial cardiocytes of the Fabry patients studied. This is in accord with negative results in the heart from patient 3 with ERT terminated (see Fig. 8b). The histochemically demonstrable $\alpha$-GALA activity in cardiocytes of ERT-treated patients (and not in patient 3) fits perfectly with the conclusion (Fig. 9). Similarly, increase in activity was shown by biochemical assay in one auricular sample available. We would also like to stress that in our studies, we used cryostat sections because the enzyme was found to be 

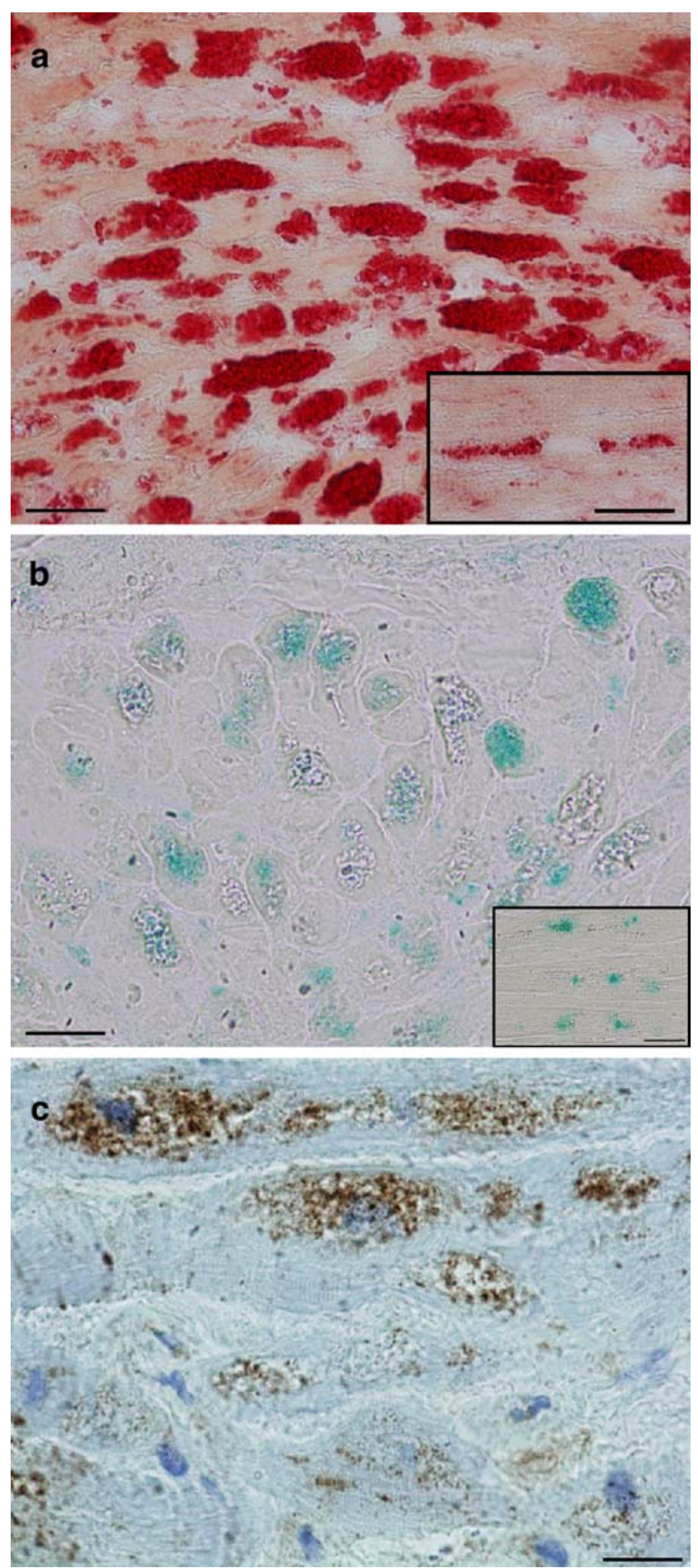

Fig. 10 Lysosomal enzyme activities and MPR immunostaining in storage atrial cardiocytes. a High and uniform activity of acid phosphatase (aqueous medium). Insert shows activity in controls (bars $50 \mathrm{~mm}$ ). b Heterogenous activity of $\beta$-galactosidase with remarkably low values in some cardiocytes. Insert shows activity in control cardiocytes (bars $50 \mathrm{~mm}$ ). c Similarly heterogeneous signal for MPR (bar $30 \mathrm{~mm})$ remarkably fixation-sensitive (see below). Therefore, sensitivity of our detection of the applied enzyme was higher than that in previous reports $[20,29]$.

The sensitivity of the applied enzyme to aldehyde fixation prevented its localization inside storage lysosomes at the electron microscope level. However, results in both cryostat and LR-White-embedded sections (Fig. 8a,d-f) indicate at least partial successive delivery of the enzyme. Its quantity may play a role, as the heart in Fabry disease may express storage even in cases with relatively high residual activity [30]. We would like to hypothesize that there may be modification of membranes of the endosomal/ lysosomal compartment, induced by longstanding storage, especially in cells with low regeneration potential, cardiocytes being an ideal example. Such modification could lead to decreased effectiveness of the contact of the storage compartment with the endocytotic delivery of the applied recombinant enzyme. Decrease in MPR in many of the storage cardiocytes suggests a changed proportion of lysosomes to late endosomes, and this may result in altered fusion, inevitable for delivery of the applied enzyme cargo to the latter $[8,25]$. It might also indicate disturbed contact even with the Golgi apparatus, which might explain low activities of $\beta$-glucuronidase, $\beta$-galactosidase, and cathep$\sin \mathrm{D}$ in the cardiocyte storage compartment. Further, parallel deposition of lipopigment (see above) points to irreversible modification of storage lysosomes. Any relevant comparison with the mouse model of Fabry disease is difficult, as the mouse cardiocytes do not seem to display storage regularly [21]. Nothing is known about the effective interaction of the applied agalsidase with Sap B in Fabry disease. The disorder, featured by densely packed lysosomal lipid membranes, differs substantially from the welldefined physiologic conditions [22]. Decreased amount of Sap B in Fabry disease [28] may aggravate the situation. In sum, one of the critical factors in ERT of Fabry disease may, thus, be the degree of storage and physical status of the stored Gb3Cer and availability of Sap B. All this raises an important question whether the effective targeting of the enzyme to the storage cell is the only prerequisite for effective ERT.

The last factor awaiting evaluation is the role of storage cell turnover in Fabry disease (and in other lysosomal storage disease). In the case of endothelial cells in Fabry disease, preliminary results (J. Bultas, personal communication) showed its increase. Therefore, the positive effect of ERT might be also explained as a replacement effect of storage cells by the endothelial cell progenitors $[1,5,17]$ that may easily endocytose the applied enzyme and thus prevent storage. This mechanism does not come into consideration in the case of post-mitotic storage cells, typically cardiocytes. Taken together, our observations speak in favor of the strategy of early treatment to prevent 
development of storage and of irreversible modulation of post-mitotic cells or of cells with low regeneration potential (cardiocytes, smooth muscle cells) and of their lysosomes. This would be the most effective prevention of irreversible tissue changes. Studies on mouse model which would compare effectiveness of early ERT (starting immediately after birth) with its delayed application in adulthood are desirable.

\section{Conclusions}

We suggest that future studies should focus on defining the differences between the storage cell, the storage compartment and their wild-type counterparts, and on possible replacement of cell populations with higher turnover by their enzyme supplied precursors. Then, enzyme replacement treatment should probably be better conceptualized as an enzyme preventive therapy (see also [19]).

Acknowledgment We wish to thank Transkaryotic Therapies Inc., Cambridge, MA, USA for providing us with agalsidase alpha and rabbit polyclonal antibody TK88. We also wish to thank the Genzyme Corporation, Cambridge, MA, USA for providing us with agalsidase beta and the corresponding monoclonal antibodies against $\alpha$ galactosidase A. We also acknowledge providing samples from patient 3 (Dr. G.A. Lammie, Univ. Hospital Wales, Cardiff) and his clinical data (Dr. P. Deegan, Department of Medicine, University of Cambridge).

This work was supported by grants from the Grant Agency of Charles University, Prague, no. 42/2005/c (to JL), from the Grant Agency of the Czech Republic, no. 303/03H065 (to JK and JL), and by the research project MSM 0021620806 from the Ministry of Education and Youth of the Czech Republic (to ME).

Conflict of interest statement We declare that we have no conflict of interest.

\section{References}

1. Asahara T, Murohara T, Sullivan A, Silver M, van der Zee R, Li T, Witzenbichler B, Schatteman G, Isner JM (1997) Isolation of putative progenitor endothelial cells for angiogenesis. Science 275:964-967

2. Asfaw B, Ledvinova J, Dobrovolny R, Bakker HD, Desnick RJ, Van Diggelen OP, De Jong JG, Kanzaki T, Chabas A, Maire I, Conzelmann E, Schindler D (2002) Defects in degradation of blood group A and B glycosphingolipids in Schindler and Fabry diseases. J Lipid Res 43:1096-1104

3. Blom D, Speijer D, Linthorst GE, Donker-Koopman WG, Strijland A, Aerts JM (2003) Recombinant enzyme therapy for Fabry disease: absence of editing of human alpha-galactosidase A mRNA. Am J Hum Genet 72:23-31

4. Bolte S, Cordelieres FP (2006) A guided tour into subcellular colocalization analysis in light microscopy. J Microsc 224:213232

5. Boyer M, Townsend LE, Vogel LM, Falk J, Reitz-Vick D, Trevor KT, Villalba M, Bendick PJ, Glover JL (2000) Isolation of endothelial cells and their progenitor cells from human peripheral blood. J Vasc Surg 31:181-189

6. Brady RO, Schiffmann R (2000) Clinical features of and recent advances in therapy for Fabry disease. JAMA 284:2771-2775

7. Brenner BM, Grunfeld JP (2004) Renoprotection by enzyme replacement therapy. Curr Opin Nephrol Hypertens 13:231241

8. Bright NA, Gratian MJ, Luzio JP (2005) Endocytic delivery to lysosomes mediated by concurrent fusion and kissing events in living cells. Curr Biol 15:360-365

9. Desnick R, Ioannou YA, Eng CM (2001) Alpha-galactosidase A deficiency: Fabry disease. In: Scriver CR, Beaudet AL, Sly WS, VAlle D (eds) The metabolic and molecular bases of inherited disease. McGraw-Hill, New York, pp 3733-3774

10. Dobrovolny R, Dvorakova L, Ledvinova J, Magage S, Bultas J, Lubanda JC, Elleder M, Karetova D, Pavlikova M, Hrebicek M (2005) Relationship between X-inactivation and clinical involvement in Fabry heterozygotes. Eleven novel mutations in the alphagalactosidase A gene in the Czech and Slovak population. J Mol Med 83:647-654

11. Elleder M (2003) Sequelae of storage in Fabry diseasepathology and comparison with other lysosomal storage diseases. Acta Paediatr Suppl 92:46-53 discussion 45

12. Eng CM, Banikazemi M, Gordon RE, Goldman M, Phelps R, Kim L, Gass A, Winston J, Dikman S, Fallon JT, Brodie S, Stacy CB, Mehta D, Parsons R, Norton K, O, Callaghan M, Desnick RJ (2001a) A phase 1/2 clinical trial of enzyme replacement in Fabry disease: pharmacokinetic, substrate clearance, and safety studies. Am J Hum Genet 68:711-722

13. Eng CM, Guffon N, Wilcox WR, Germain DP, Lee P, Waldek S, Caplan L, Linthorst GE, Desnick RJ (2001b) Safety and efficacy of recombinant human alpha-galactosidase A-replacement therapy in Fabry's disease. N Engl J Med 345:9-16

14. Genzyme, Corporation (2001) Product Monograph, Enzyme replacement therapy for Fabry disease

15. Germain DP, Waldek S, Banikazemi M, Bushinsky DA, Charrow J, Desnick RJ, Lee P, Loew T, Vedder AC, Abichandani R, Wilcox WR, Guffon N (2007) Sustained, long-term renal stabilization after 54 months of agalsidase beta therapy in patients with Fabry disease. J Am Soc Nephrol 18:1547-1557

16. Hartree EF (1972) Determination of protein: a modification of the Lowry method that gives a linear photometric response. Anal Biochem 48:422-427

17. Hernandez DA, Townsend LE, Uzieblo MR, Haan ME, Callahan RE, Bendick PJ, Glover JL (2000) Human endothelial cell cultures from progenitor cells obtained by leukapheresis. Am Surg 66:355-358 discussion 359

18. Hille-Rehfeld A (1995) Mannose 6-phosphate receptors in sorting and transport of lysosomal enzymes. Biochim Biophys Acta 1241:177-194

19. Hollak CE, Vedder AC, Linthorst GE, Aerts JM (2007) Novel therapeutic targets for the treatment of Fabry disease. Expert Opin Ther Targets 11:821-833

20. Christensen EI, Zhou Q, Sorensen SS, Rasmussen AK, Jacobsen C, Feldt-Rasmussen U, Nielsen R (2007) Distribution of alphagalactosidase $\mathrm{A}$ in normal human kidney and renal accumulation and distribution of recombinant alpha-galactosidase A in Fabry mice. J Am Soc Nephrol 18:698-706

21. Ioannou YA, Zeidner KM, Gordon RE, Desnick RJ (2001) Fabry disease: preclinical studies demonstrate the effectiveness of alphagalactosidase A replacement in enzyme-deficient mice. Am J Hum Genet 68:14-25

22. Kolter T, Sandhoff K (2006) Sphingolipid metabolism diseases. Biochim Biophys Acta 1758:2057-2079 
23. Lee K, Jin X, Zhang K, Copertino L, Andrews L, Baker-Malcolm J, Geagan L, Qiu H, Seiger K, Barngrover D, McPherson JM, Edmunds T (2003) A biochemical and pharmacological comparison of enzyme replacement therapies for the glycolipid storage disorder Fabry disease. Glycobiology 13:305-313

24. Lojda Z, Gossrau R, Schiebler TH (1979) Enzyme histochemistry. A laboratory manual. Springer, Berlin

25. Luzio JP, Pryor PR, Gray SR, Gratian MJ, Piper RC, Bright NA (2005) Membrane traffic to and from lysosomes. Biochemical Society Symposium, pp 77-86

26. Manders EMM, Verbeek FJ, Aten JA (1993) Measurement of colocalization of objects in dual-color confocal images. J Microsc-Oxford 169:375-382

27. Mayes JS, Scheerer JB, Sifers RN, Donaldson ML (1981) Differential assay for lysosomal alpha-galactosidases in human tissues and its application to Fabry's disease. Clin Chim Acta 112:247-251

28. Morimoto S, Yamamoto Y, O, Brien JS, Kishimoto Y (1990) Distribution of saposin proteins (sphingolipid activator proteins) in lysosomal storage and other diseases. Proc Natl Acad Sci U S A 87:3493-3497

29. Murray GJ, Anver MR, Kennedy MA, Quirk JM, Schiffmann R (2007) Cellular and tissue distribution of intravenously administered agalsidase alfa. Mol Genet Metab 90:307-312

30. Nakao S, Takenaka T, Maeda M, Kodama C, Tanaka A, Tahara M, Yoshida A, Kuriyama M, Hayashibe H, Sakuraba H et al (1995) An atypical variant of Fabry's disease in men with left ventricular hypertrophy. N Engl J Med 333:288-293

31. Rasband WS (1997-2006). "ImageJ", from http://rsb.info.nih.gov/ij/

32. Rozenfeld PA, Croxatto O, Ebner R, Fossati CA (2006) Immunofluorescence detection of globotriaosylceramide deposits in conjunctival biopsies of Fabry disease patients. Clin Exp Ophthalmol 34:689-694

33. Sakuraba H, Murata-Ohsawa M, Kawashima I, Tajima Y, Kotani M, Ohshima T, Chiba Y, Takashiba M, Jigami Y, Fukushige T, Kanzaki T, Itoh K (2006) Comparison of the effects of agalsidase alfa and agalsidase beta on cultured human Fabry fibroblasts and Fabry mice. J Hum Genet 51:180-188
34. Seehafer SS, Pearce DA (2006) You say lipofuscin, we say ceroid: defining autofluorescent storage material. Neurobiol Aging 27:576-588

35. Schiffmann R, Murray GJ, Treco D, Daniel P, Sellos-Moura M, Myers M, Quirk JM, Zirzow GC, Borowski M, Loveday K, Anderson T, Gillespie F, Oliver KL, Jeffries NO, Doo E, Liang TJ, Kreps C, Gunter K, Frei K, Crutchfield K, Selden RF, Brady RO (2000) Infusion of alpha-galactosidase A reduces tissue globotriaosylceramide storage in patients with Fabry disease. Proc Natl Acad Sci U S A 97:365-370

36. Schiffmann R, Rapkiewicz A, Abu-Asab M, Ries M, Askari H, Tsokos M, Quezado M (2006) Pathological findings in a patient with Fabry disease who died after 2.5 years of enzyme replacement. Virchows Arch 448:337-343

37. Simionescu M, Gafencu A, Antohe F (2002) Transcytosis of plasma macromolecules in endothelial cells: a cell biological survey. Microsc Res Tech 57:269-288

38. Stern AS, Klotman ME, Ioannou YA, Burrow CR, Wilson PD, Klotman PE, Lipkowitz MS (2002) Polarity of alpha-galactosidase A uptake by renal tubule cells. Kidney Int 61:52-55

39. Thurberg BL, Randolph Byers H, Granter SR, Phelps RG, Gordon RE, O, Callaghan M (2004) Monitoring the 3-year efficacy of enzyme replacement therapy in Fabry disease by repeated skin biopsies. J Invest Dermatol 122:900-908

40. Thurberg BL, Rennke H, Colvin RB, Dikman S, Gordon RE, Collins AB, Desnick RJ, O, Callaghan M (2002) Globotriaosylceramide accumulation in the Fabry kidney is cleared from multiple cell types after enzyme replacement therapy. Kidney Int 62:1933-1946

41. TKT, Europe (2001) Information Brochure, Enzyme replacement therapies for Fabry disease.

42. Wenk J, Hille A, von Figura K (1991) Quantitation of Mr 46000 and $\mathrm{Mr} 300000$ mannose 6-phosphate receptors in human cells and tissues. Biochem Int 23:723-731

43. Wilcox WR, Banikazemi M, Guffon N, Waldek S, Lee P, Linthorst GE, Desnick RJ, Germain DP (2004) Long-term safety and efficacy of enzyme replacement therapy for Fabry disease. Am J Hum Genet 75:65-74 